\section{Landscape Growth and Aesthetic Quality of Coleus Managed with Irrigation Deficits}

\author{
S.M. Scheiber ${ }^{1,3}$ and Richard C. Beeson, Jr. ${ }^{2}$
}

AdDITIONAL INDEX WORDs. drainage lysimeter, tensiometer, water management, Solenostemon scutellarioides

SuMmary. Previous research indicated that bedding plants can be maintained in landscape soils allowed to dry to substantially less than field capacity before irrigation; however, canopy size and aesthetic quality were compromised. Continuing this research, 'Yalaha' coleus (Solenostemon scutellarioides) were grown in drainage lysimeters in an open-sided clear polyethylene-covered shelter and a companion uncovered field plot to assess growth characteristics and landscape quality when irrigated at various managed allowable deficits. Using tensiometers, plants were irrigated back to field capacity when plant-available water within a soil was depleted to $70 \%$ or $50 \%$. Deficits were evaluated against a control treatment of 0.5 inch daily irrigation. Total irrigation volume applied was significantly greater for the control treatments than deficit irrigation treatments. The net result was $78 \%$ and $90 \%$ average reductions in total volume applied to lysimeter and field-grown coleus respectively. On average, height was $\mathbf{2 0 \%}$ and $\mathbf{1 5 \%}$ greater for well-watered controls grown in lysimeters and field plots respectively than plants grown in deficit irrigations. Canopy size of nondeficit controls was $26 \%$ and $72 \%$ greater on average than deficit treatments in lysimeter and field plots respectively. However, shoot and root dry weights, total biomass, shoot-to-root ratios, and landscape quality were similar among treatments for both locations.

A s demands on potable water supplies increase, water management officials are seeking solutions beyond restrictions on irrigation schedules. Demand-based irrigation systems such as tensiometers monitor soil moisture levels then deliver irrigation based on plant water consumption. Without compromising growth or aesthetic quality, tensiometer-regulated systems reduced irrigation volumes applied to 'Santorini' carnations (Dianthus caryophyllus), cucumbers (Cucumis sativus), and 'Kardinal' roses (Rosa bybrida) (Ells et al., 1989; Oki et al., 2001; Taylor et al., 2004). Combined with conventional automated time clocks, tensiometers can apply irrigation volumes that maintain soil moisture at optimum levels for growth.

Sustainability is the objective of landscape maintenance, not maximum growth. Sachs et al. (1975) found that growth was closely correlated to irrigation frequency, but aesthetically, established landscape

University of Florida, IFAS, Environmental Horticulture Department, MREC, 2725 Binion Road, Apopka, FL 32703

${ }^{1}$ Assistant Professor

${ }^{2}$ Associate Professor

${ }^{3}$ Corresponding author. E-mail: scheiber@ufl.edu. shrubs and groundcovers could be maintained at reduced irrigation levels. Termed either managed allowable deficits or regulated deficit irrigation, the concept is defined as a preset level that soil or substrate is allowed to dry before irrigation. Deficit irrigation has been successfully used in container production of red tip photinia (Photina $\times$ fraseri), sweet viburnum (Viburnum odoratissimum), japanese privet (Ligustrum japonicum), and indian hawthorn (Rbaphiolepis indica), as well as field production of spinach (Spinacea oleracea) and spring wheat (Triticum aestioum) (Beeson, 2006; Leskovar and Piccinni, 2005; Welsh and Zajicek, 1993; Zhang et al., $2005)$. Significant reductions in application volumes were found with equivalent or greater growth and quality than nondeficit controls.

The concept has not been not widely used in urban environments. However, recent studies have investigated deficit irrigation responses for residential and commercial turfgrass applications. At $70 \%$ replacement of well-watered actual evapotranspiration $\left(\mathrm{ET}_{\mathrm{A}}\right)$, performance and quality of buffalograss (Buchloe dactyloides) and zoysiagrass (Zoysia spp.) grown for residential lawns were comparable with grasses receiving $100 \% \mathrm{ET}_{\mathrm{A}}$ replacement (Henry et al., 2005). Furthermore, creeping bentgrass (Agrostis stolonifera), colonial bentgrass ( $A$. capillaries), and velvet bentgrass ( $A$. canina) irrigated at $60 \%$ to $80 \%$ replacement of $100 \% \mathrm{ET}_{\mathrm{A}}$ were maintained at acceptable quality levels for golf course fairways (DaCosta and Huang, 2006). Previous research on 'Midnight' petunia (Petunia $\times$ bybrida) found tensiometers programmed to irrigate at $50 \%$ of plant-available water (PAW) significantly reduced irrigation volumes, but aesthetic quality and canopy size were compromised in simulated landscapes (Scheiber and Beeson, 2006). The objectives of this study are 1) to evaluate the effectiveness of deficit irrigation controlled by tensiometers for reducing irrigation volumes and 2) to evaluate the effect of various irrigation deficits on growth and aesthetic quality of coleus.

\section{Materials and methods}

'Yalaha' coleus were obtained from a commercial nursery in 4inch-diameter containers and transplanted on 9 June 2005 into drainage lysimeters and an uncovered companion field plot of deep, highly drained fine sand (Apopka fine sand series) with a $\mathrm{pH}$ of 7.4. Each lysimeter was constructed from rigid plastic containers (\#65; Lerio Corp., Kissimmee,

\begin{tabular}{llll}
\hline $\begin{array}{l}\text { Units } \\
\text { To convert U.S. to SI, } \\
\text { multiply by }\end{array}$ & U.S. unit & SI unit & $\begin{array}{l}\text { To convert SI to U.S., } \\
\text { multiply by }\end{array}$ \\
\hline 10 & $\%$ & $\mathrm{~g} \cdot \mathrm{L}^{-1}$ & 0.1 \\
100 & $\mathrm{bar}(\mathrm{s})$ & $\mathrm{kPa}$ & 0.01 \\
0.1 & $\mathrm{bar}(\mathrm{s})$ & $\mathrm{MPa}$ & 10 \\
0.3048 & $\mathrm{ft}$ & $\mathrm{m}$ & 3.2808 \\
3.7854 & $\mathrm{gal}$ & $\mathrm{L}$ & 0.2642 \\
2.5400 & inch(es) & $\mathrm{cm}$ & 0.3937 \\
25.4000 & inch(es) & $\mathrm{mm}$ & 0.0394 \\
16.3871 & inch & $\mathrm{cm}$ & 0.0610 \\
48.8243 & lb $/ 1000 \mathrm{ft}^{2}$ & $\mathrm{~kg} \cdot h \mathrm{~h}^{-1}$ & 0.0205 \\
28.3495 & $\mathrm{oz}$ & $\mathrm{g}$ & 0.0353 \\
$\left({ }^{\circ} \mathrm{F}-32\right) \div 1.8$ & ${ }^{\circ} \mathrm{F}$ & ${ }^{\circ} \mathrm{C}$ & $\left(1.8 \times{ }^{\circ} \mathrm{C}\right)+32$
\end{tabular}

Hortechnology · October-December 2007 17(4) 
FL) with a diameter of 35 inches and a depth of 18 inches, and located in an open-sided clear polyethylene covered shelter. Lysimeters were backfilled with native top soil (Apopka fine sand) to simulate landscape conditions. Lysimeters were elevated $1.5 \mathrm{ft}$ above the ground surface to facilitate drainage. To minimize the impact of solar radiation on root temperatures, exteriors of each plastic container were coated with white exterior latex flat house paint (Enterprise Paint Co., Wheeling, IL).

Lysimeters and the companion field plot were managed as recommended by Black and Gilman (1998) for bedding plants in Florida landscapes. Controlled-release fertilizer was uniformly broadcast immediately after transplanting with a standard nitrogen rate of $4 \mathrm{lb} / 1000 \mathrm{ft}^{2}$ from $18 \mathrm{~N}-2.6 \mathrm{P}-9.9 \mathrm{~K}$ Osmocote (Scotts Co., Marysville, OH). A 9-month fertilizer was chosen based on previous research that Osmocote only lasts $\approx 4$ months in central Florida during the summer (Beeson, 1996). At 1 month after transplant (MAT), marked differences in shoot growth were observed between lysimeter and field growth. Differences were attributed to unseasonably high rainfall (12.5 inches), although a soil analysis was not performed. To compensate for potential losses resulting from leaching, a second fertilizer application at the same rate was applied to the companion field plot 1 MAT. However, differences likely resulted from a severe root knot nematode infestation (Meloidogyne spp.) that was discovered during root harvest.

The experiment was conducted as a randomized complete-block design with three irrigation regimes: $100 \%$ PAW (control), 70\% PAW, or $50 \%$ PAW. The control treatment received 0.5 inch of irrigation daily as recommended for bedding plants in Florida landscapes (Black and Gilman, 1998). Lysimeters and the companion field plot were not compared because location was not replicated. Each irrigation regime was replicated three times with three plants per replicate.

Irrigation regimes were initiated immediately after transplant. Using tensiometers equipped with microswitches (model LTA-12; Irrometer Co., Riverside, CA) wired in series with an automated irrigation controller, plants were irrigated back to field capacity when PAW had been depleted to $70 \%$ or $50 \%$ of field capacity $(2.5 \mathrm{kPa}$ to $1.5 \mathrm{MPa}$; total of $21 \mathrm{~cm}^{3}$ per $100 \mathrm{~cm}^{3}$ of soil). One tensiometer was installed in each lysimeter adjacent to the root ball of the westernmost plant, such that the bottom of its porous cup was at the same depth as the bottom of a root ball $(10 \mathrm{~cm}$ below the soil surface) as recommended by Hensley and Deputy (1999). Irrigation was initiated when current was supplied by the irrigation controller and the microswitch on the tensiometer was closed resulting from decreases in soil matric potential below the set point. Irrigation ran until sufficient water infiltrated to the depth of the porous cup to increase matric potential sufficiently to open the microswitch, closing the electric water valve. Plant soil moisture availability was calculated from soil water dehydration curves (Klute, 1986).

Irrigation was applied within each lysimeter and companion field plot from three microirrigation spray stakes equipped with a half-circle spreader (model Stake 31; Spreader Red 180, Dan Sprinklers, Kibbutz Dan, Israel) situated in a triangular pattern with each emitter 18 inches apart and mounted 3 inches above ground level. The combined flow rate was $2.86 \mathrm{~L} \cdot \mathrm{min}^{-1}(4.6$ $\left.\mathrm{mm} \cdot \mathrm{min}^{-1}\right)$. The Christiansen coefficient of uniformity was a minimum of 0.99 before planting (Haman et al., 2005).

Irrigation of each lysimeter and corresponding field plots was controlled as separate zones using an automated irrigation time clock (model Sterling 12; Superior Controls Co., Valencia, CA). Irrigations were applied Sunday through Saturday and began at $0500 \mathrm{HR}$ and were completed by 0600 HR each day. Flow meters (model C700TP; ABS, Ocala, FL) were installed for each lysimeter and field plots to record irrigation volumes Monday through Friday. Weekend irrigation volumes were included in total volume recorded the following Monday. Recorded volumes were used to verify that lysimeters and field plots were irrigated back to field capacity to at least a 6-inch depth.

GrowTH INDEXES AND BIOMASS. Measurements of average canopy height, largest canopy width, and the width perpendicular to the largest width were recorded to calculate growth indices as volume (growth index $=$ height $\times$ width $1 \times$ width 2 ). All plants were measured immediately after transplanting and every 4 weeks thereafter until final harvest. The experiment was ended on 22 Sept. 2005 [ $104 \mathrm{~d}$ after transplant (DAT)]. To calculate shoot-to-root ratios, shoots were severed at the soil line and dried at $149^{\circ} \mathrm{F}$ until constant dry weight was obtained. Coleus initiated flowering during the final month of the experiment, but only sparingly and uniformly across treatments. Inflorescences were not removed and were included in the shoot harvest. To obtain root dry weight, each lysimeter was subsampled such that the northeastern one-third of the soil volume spanning the depth of the lysimeter was removed. In the companion field plot, the northeastern one-third segment of the soil volume spanning the depth of the deepest root and width of the longest root was removed. Soil was removed from roots, and roots were dried as described for shoots. Total root weight was calculated by multiplying measured root weight by three.

LEAF WATER POTENTIAL AND LEAF gAS EXCHANGE MEASUREMENTS. Stomatal conductance $\left(g_{s}\right)$ was measured at 30 and 45 DAT (scheduled midpoint of the experiment) on all replicate $\times$ treatment combinations grown in drainage lysimeters and the companion field plot. Measurements were taken every 2 h between $900 \mathrm{HR}$ and $1600 \mathrm{HR}$. Measurements were taken randomly on one leaf in each lysimeter and corresponding field plot replication with a steady-state porometer (LI-1500; LI-COR, Lincoln, NE).

Climatic Data. Daily climatic data were obtained from the Florida Automated Weather Station located $50 \mathrm{~m}$ from the site. Photosynthetic photon flux $(P P F)$ was measured within the rainout shelter with a sunfleck ceptometer (Decagon Devices, Pullman, WA), and a $12 \%$ reduction in PPF was noted.

LANDSCAPE QUALITY. Landscape quality, based on aesthetic appearance, was rated monthly by three subjects on a scale of 1 point (dead) to 5 points (mounded, proportional form; dense; complete coverage, no dieback). Ratings were averaged across subjects. 
Data Analysis. The experiment was conducted as a randomized complete-block design with three blocks of single replicates. Both the companion field plots and the lysimeters contained all three treatments in each block for a total of nine companion field plots and nine lysimeters. Data were analyzed separately by location (i.e., drainage lysimeters, companion field plot) because location was not replicated. Regression equations were calculated for growth indices and plant height over time for each irrigation regime. When all equations within a comparison were linear, slopes were compared using single$\mathrm{df}$ contrast and intercepts as suggested by Snedecor and Cochran (1980). For growth indices and plant height, when at least one of the regression lines was quadratic, data were analyzed by split plot, with irrigation regime as the main plot and DAT as the subplot. Growth indices and height from each sampling period (DAT) were also analyzed separately as a one-way analysis of variance (ANOVA) with general linear model (GLM). Final growth data, consisting of plant height, growth index, shoot dry weight, root dry weight, total biomass, and shoot-to-root ratios, were analyzed as a one-way ANOVA with GLM, with three irrigation treatments and three replications. Cumulative irrigation was analyzed using a one-way ANOVA with GLM. Stomatal conductance was averaged over the day for each sampling date and analyzed as repeated measures using a split-plot design with irrigation regime as the main plot and DAT as a subplot (Snedecor and Cochran, 1980). When significant differences were indicated, mean separation was by Fisher's protected LSD (Snedecor and Cochran, 1980). Landscape quality was analyzed by NPARIWAY Wilcoxon KruskalWallis. When differences in landscape quality were indicated, means separation was by Wilcoxon two-sample test (Howell, 2004). All analyses were conducted using SAS (version 9.1.3; SAS Institute, Cary, NC).

\section{Results and discussion}

IRRIGATION AND WATER STRESS. Total irrigation volume applied was greater $(P<0.01)$ for the control treatment than deficit irrigation treatments for either location (Tables 1 and 2). The net result was $78 \%$ and $90 \%$ average reductions in total volume applied to lysimeter and fieldgrown coleus respectively. Application volumes were similar $(P>0.05)$ among deficit treatments within both lysimeter and field-grown plots (Tables 1 and 2). Oki et al. (2001) reported a $26 \%$ reduction in application volumes using tensiometers for deficit irrigation and a $66 \%$ increase in harvestable stems of 'Kardinal' roses relative to nondeficit irrigation. Comparable results were reported for spring wheat, for which a $15 \%$ reduction in irrigation volume from deficit irrigation corresponded with an approximate $27 \%$ increase in yield and

Table 1. Drainage lysimeter irrigation volumes, efficiency, and stomatal conductance for 'Yalaha' coleus treated with one of three irrigation regimes: $100 \%$ plant-available water (PAW) [control, 0.5 inch $(12.70 \mathrm{~mm})$ irrigation daily], $70 \%$ PAW, or $50 \%$ PAW during early to late summer in central Florida.

\begin{tabular}{|c|c|c|c|c|}
\hline Treatment & $\begin{array}{c}\text { Cumulative } \\
\text { irrigation }(\mathrm{L})^{\mathrm{z}}\end{array}$ & $\begin{array}{l}\text { Biomass production } \\
\text { efficiency }\left(g \cdot \mathrm{L}^{-1}\right)^{\mathrm{y}}\end{array}$ & $\begin{array}{l}\text { Shoot dry wt production } \\
\text { efficiency }^{\mathrm{x}}\left(\mathrm{g} \cdot \mathrm{L}^{-1}\right)\end{array}$ & $\begin{array}{l}\text { Stomatal conductance } \\
{\left[g_{s}\left(\mathrm{mmol} \cdot \mathrm{m}^{-2}\right)\right]^{\mathrm{w}}} \\
\end{array}$ \\
\hline Control & $845.7 \mathrm{a}^{\mathrm{vu}}$ & $0.32 \mathrm{~b}$ & $0.28 \mathrm{~b}$ & $232.8 \mathrm{NS}$ \\
\hline $50 \%$ PAW & $182.7 \mathrm{~b}$ & $1.38 \mathrm{a}$ & $1.26 \mathrm{a}$ & 182.0 \\
\hline$P$ & $<0.0001$ & 0.0010 & 0.0012 & $>0.05$ \\
\hline
\end{tabular}

${ }^{\mathrm{z}} \mathrm{l} \mathrm{L}=0.2642$ gal.

'Biomass production efficiency $=$ total biomass /applied irrigation volume; $1 \mathrm{~g} \cdot \mathrm{L}^{-1}=0.1 \%$.

${ }^{x}$ Shoot dry weight production efficiency $=$ total shoot dry weight/applied irrigation volume.

"Mean stomatal conductance pooled across sampling dates.

${ }^{\mathrm{M}}$ Means representative of three lysimeter replicates.

"Mean separations within columns using Fisher protected LSD at $P=0.05$; Ns, nonsignificant.

Each treatment was applied to a lysimeter with a surface area of $0.62 \mathrm{~m}^{2}\left(6.674 \mathrm{ft}^{2}\right)$ containing three plants each.

PAW, plant-available water.

Table 2. Field planting irrigation volumes, efficiency, and stomatal conductance for 'Yalaha' coleus treated with one of three irrigation regimes: $100 \%$ plant-available water (PAW) [control, 0.5 inch $(12.70 \mathrm{~mm})$ irrigation daily], $70 \% \mathrm{PAW}$, or $50 \%$ PAW during early to late summer in central Florida.

\begin{tabular}{lcccc}
\hline Treatment & $\begin{array}{c}\text { Cumulative } \\
\text { irrigation }(\mathbf{L})^{\mathbf{z}}\end{array}$ & $\begin{array}{c}\text { Biomass production } \\
\text { efficiency }\left(\mathbf{g} \cdot \mathbf{L}^{-\mathbf{1}}\right)^{\mathbf{y}}\end{array}$ & $\begin{array}{c}\text { Shoot dry wt production } \\
\text { efficiency } \mathbf{x}\left(\mathbf{g} \cdot \mathbf{L}^{-1}\right)\end{array}$ & $\begin{array}{c}\text { Stomatal conductance } \\
{\left[g_{\mathrm{s}}\left(\mathbf{m m o l} \cdot \mathbf{m}^{-2}\right)\right]^{\mathbf{w}}}\end{array}$ \\
\hline Control & $2662.5 \mathrm{a} \mathrm{vu}$ & $0.07 \mathrm{~b}$ & $0.06 \mathrm{~b}$ & $316.1 \mathrm{a}$ \\
$70 \%$ PAW & $475.3 \mathrm{~b}$ & $0.31 \mathrm{~b}$ & $0.25 \mathrm{~b}$ & $202.8 \mathrm{~b}$ \\
$50 \%$ PAW & $138.3 \mathrm{~b}$ & $1.09 \mathrm{a}$ & $0.89 \mathrm{a}$ & $109.9 \mathrm{~b}$ \\
$P$ & 0.0168 & 0.0006 & 0.0008 & 0.0291 \\
\hline
\end{tabular}

${ }^{\mathrm{z}} 1 \mathrm{~L}=0.2642 \mathrm{gal}$.

yBiomass production efficiency $=$ total biomass / applied irrigation volume; $1 \mathrm{~g} \cdot \mathrm{L}^{-1}=0.1 \%$.

${ }^{x}$ Shoot dry weight production efficiency $=$ total shoot dry weight $/$ applied irrigation volume.

"Mean stomatal conductance pooled across sampling dates.

"Means representative of three lysimeter replicates.

"Mean separations within columns using Fisher protected LSD at $P=0.05$; Ns, nonsignificant.

Each treatment was applied to a lysimeter with a surface area of $0.62 \mathrm{~m}^{2}\left(6.674 \mathrm{ft}^{2}\right)$ containing three plants each.

PAW, plant-available water. 
water use efficiency (Zhang et al., 2005). Large differences in applied irrigation volumes were noted between control treatments in lysimeters $(845.7 \mathrm{~L})$ and field plots $(2662.5$ L). These differences are attributed to irrigation containment. All water was contained within lysimeters by container walls that prevented drift outside the experimental area. Therefore, smaller irrigation volumes were required to obtain the desired 0.5 inch application depth. In addition, companion field plots received $85 \mathrm{~cm}$ or $521 \mathrm{~L}$ of rainfall during the experimental period.

Greater application volumes among controls increased $g_{s}$ for field-grown coleus with $g_{\mathrm{s}} 1.6$ - and 2.9-fold higher $(P<0.01)$ than plants irrigated at $70 \%$ and $50 \%$ PAW respectively (Table 2 ). Days after transplant had no effect on $g_{S}(P>0.05)$. Before 30 DAT, the $70 \%$ PAW treatments averaged 3.3 irrigation events. By 45 DAT, an average of 1.5 additional irrigation events was applied. Plants irrigated at $50 \%$ PAW did not irrigate before either sampling date. Similar declines in $g_{s}$ were reported for cucumbers irrigated to $70 \%$ to $75 \%$ and $55 \%$ to $60 \%$ of field capacity (Wang and Zhang, 2004) compared with well-irrigated controls. Results suggest that the combination of deficit irrigation treatments and root knot nematode infestation reduced water absorption capacity, thereby lowering $g_{s}$ in field plots compared with well-watered controls. Stomatal conductance was similar $(P>0.05)$ among treatments for lysimeter coleus (Table 1). Lysimeters irrigated at $70 \%$ and $50 \%$ PAW were irrigated on average 2 and 2.7 times respectively.

BIOMASS AND IRRIGATION EFFICIENCY. In lysimeters, shoot dry weight $(223.9 \pm 38.3 \mathrm{~g})$, root dry weight $(25.7 \pm 10.1 \mathrm{~g})$, and total biomass $(249.7 \pm 46.5 \mathrm{~g})$ were similar $(P>0.05)$ among well-watered controls and plants irrigated at $70 \%$ and $50 \%$ PAW respectively. All parameters were also similar $(P>0.05)$ among treatments for field-grown coleus. In the field, control, 70\% PAW, and $50 \%$ PAW produced $125.9 \pm 32.6 \mathrm{~g}$ of shoot dry weight, $28.2 \pm 6.8 \mathrm{~g}$ of root dry weight, and $154.7 \pm 38.4 \mathrm{~g}$ of biomass. Reduced shoot weight in the field plot was most likely a result of the root knot nematode infestation. Shoot-to-root ratios were similar $(P>0.05)$ among treatments for both lysimeter and field-grown coleus, although ratios were lowest within the control treatment (data not shown). Varying effects on yield have been reported in response to deficit irrigations. Smajstrla and Locascio (1996) found tomato (Solanum lycopersicum) yield declined as soil matric tension increased from 10 to $20 \mathrm{kPa}$, yet Calado et al. (1992) reported the opposite effect, with tomato yield increasing as tensions increased. Cut flower production of carnation irrigated between 15 to $75 \mathrm{kPa}$ yielded similar flower numbers, although marketable quality differed (Taylor et al., 2004).

Higher irrigation volumes applied to controls, yet with similar dry weight production to deficit irrigation regimes combined to reduce $(P<$ 0.01 ) biomass and shoot dry weight efficiency approximately fourfold for lysimeter control plants (Table 1$)$. Efficiencies were similar $(P>0.05)$ between deficit irrigation treatments. In the field, biomass and shoot dry weight efficiency were greatest
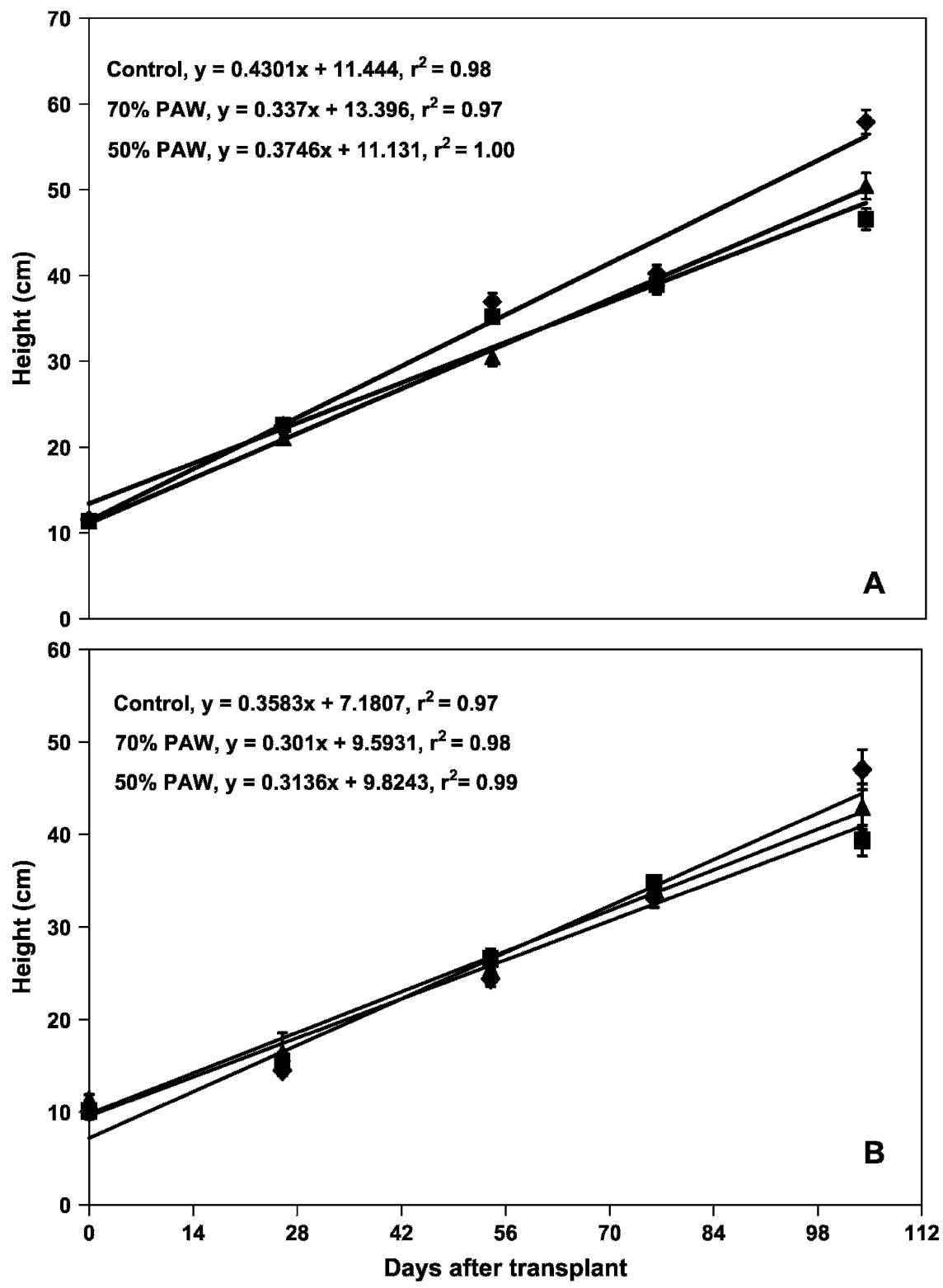

Fig. 1. (A, B) Mean heights of 'Yalaha' coleus treated with three irrigation regimes: (४) $100 \%$ plant-available water (PAW) [control, 0.5 inch $(12.70 \mathrm{~mm})$ irrigation

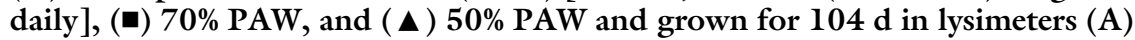
and companion field plots $(B)$ in central Florida. Each point represents the means of three replications with \pm SE indicated by bars. $1 \mathrm{~cm}=0.3937$ inch. 
$(P<0.05)$ at $50 \%$ PAW, with efficiency of controls declining $\approx 15$-fold. Plants irrigated at 70\% PAW declined $\approx 3.5$-fold in both biomass and shoot dry weight efficiency compared with the 50\% PAW (Table 2). Highest irrigation efficiency on a weight basis was also reported for lettuce [Lactuca sativa (Agglelides et al., 1999)] and sugar beet [Beta vulgaris (Kiziloglu et al., 2006)] at the lowest soil matric potential treatment.

Canopy SIZE and height. Irrigation regime impacted plant height growth rates for lysimeter and fieldgrown coleus (Fig. 1). Plant height increased linearly $(P<0.0001)$ in both locations (Fig. 1). Well-watered controls increased plant height on average 1.2 times faster $(P<0.05)$ than deficit-irrigated plants in lysimeters. Final height was $25 \%$ and $15 \%$ larger $(P<0.0001)$ among lysimeter controls compared with $70 \%$ and $50 \%$ treatments respectively (Fig. 1A). Slopes of the height versus DAT were similar between deficit irrigation regimes $(P>0.05)$. Before termination of the experiment, heights were similar among treatments except at 54 DAT (Fig. 1A). Height decreased $(P<0.05)$ at $50 \%$ PAW compared with other treatments. For field coleus, height increased 1.1 times faster on average $(P<0.05)$ for control and 50\% PAW treatments than the $70 \%$ regime, with final height $20 \%$ and $9 \%$ larger respectively (Fig. 1B). Heights at all previous dates were similar among treatments (Fig. 1B). Reductions in height of $40 \%$ occurred in 'Leuchtfeuer' hydrangea (Hydrangea macrophylla) in response to deficit irrigation (Morel, 2001).

Canopy size increased quadratically in both locations $(P<0.05$; Fig. 2), with interactions between irrigation regime and DAT. In lysimeters, size was greatest among all regimes 104 DAT, with controls around $26 \%$ larger $(P<0.05)$ than the deficit treatments (Fig. 2A). Similar results were found in the field, with controls $82 \%$ and $63 \%$ larger than $70 \%$ and $50 \%$ PAW treatments respectively (Fig. 2B). Differences among treatments were also noted at 54 and 76 DAT for lysimeter coleus, with canopy size significantly decreasing as PAW declined (Fig. 2A). Low irrigation frequency and volume, combined with root damage from

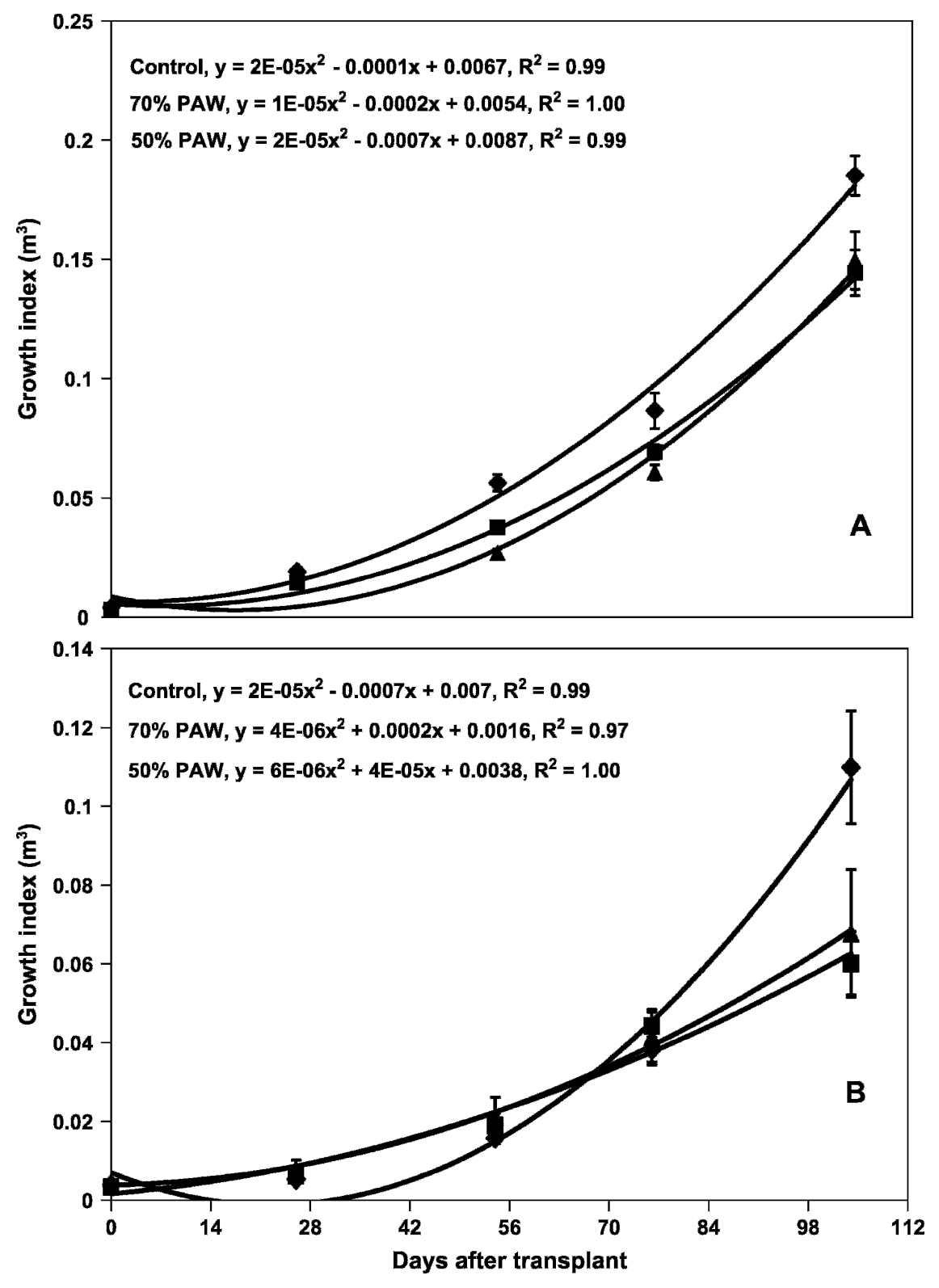

Fig. 2. Mean growth indices of 'Yalaha' coleus treated with three irrigation regimes: ( ) $100 \%$ plant-available water (PAW) [control, 0.5 inch $(12.70 \mathrm{~mm})$ irrigation daily], (ロ) 70\% PAW, and ( $\triangle$ ) 50\% PAW and grown for $104 \mathrm{~d}$ in lysimeters (A) and companion field plots $(B)$ in central Florida. Each point represents the means of three replications with $\pm \mathrm{SE}$ indicated by bars. $1 \mathrm{~m}^{3}=35.3147 \mathrm{ft}^{3}$.

root knot nematodes, severely stunted the deficit irrigation treatments. Canopy sizes were similar $(P>0.05)$ between deficit irrigation regimes within each location at termination of the experiment (104 DAT). Reductions in canopy size in response to deficit irrigation are common, as reported by Beeson (2006).

Throughout Florida, daily irrigation is recommended for perennials and annuals during the establishment phase. After establishment, recommendations advise irrigation based on an "as-needed" basis (Trenholm et al., 2002). However, overirrigation by as much as $40 \%$ is prevalent because homeowners and landscape professionals do not understand or are unaware of consumption requirements of landscape plants (Thayer, 1982). Compounding the problem is failure to reset automated time clocks after establishment (Dukes et al., 2005).

In the current study, coleus with equivalent biomass and landscape quality $(P>0.05$; data not shown $)$ were established and maintained in 
landscapes using tensiometers programmed to irrigate when up to $50 \%$ of PAW in sand soils had been depleted, even in the absence of supplemental rainfall. Similar lysimeter and deficit irrigation conditions previously failed to produce aesthetically acceptable petunia plants in a simulated landscape (Scheiber and Beeson, 2006). In the current study, canopy size and height of the treatment coleus were reduced compared with well-watered controls. Reductions in canopy size must be balanced against potential water savings. Daily irrigation over the $104 \mathrm{~d}$ of this experiment increased irrigation application volumes above those used in the deficit irrigation regimes at magnitudes of 4.6- and 19.3-fold for lysimeter and field-grown coleus respectively.

Although tensiometers are an effective method for managing deficit irrigation, they do require routine maintenance. Alternative demandbased systems such as ET-based controllers and dielectric probes are available that offer the same water saving benefits as tensiometers without the maintenance. However, each has its drawbacks, such as high equipment costs or complex installation. Simpler methods such observation of wilt can also be used, but aesthetic quality will be compromised. The choice of method will be dependent on cost, time, and the desired appearance of the landscape. Regardless of the method used, coleus can be established and maintained in the landscape with deficit irrigation regimes up to $50 \%$ PAW without compromising aesthetics or biomass accumulation while substantially reducing irrigation.

\section{Literature cited}

Agglelides, S., I. Asimakopoulos, P. Kerkides, and A. Skondras. 1999. Effects of soil water potential on the nitrate content and yield of lettuce. Commun. Soil Sci. Plant Anal. 30:235-243.

Black, R.J. and E.F. Gilman. 1998. Your Florida guide to bedding plants: Selection, establishment, and maintenance. University of Florida Press, Gainesville, FL.

Beeson, R.C., 1996. Composted yard waste as a component of container substrates. J. Environ. Hort. 14:115-121.
Beeson R.C., Jr. 2006. Relationship of plant growth and actual evapotranspiration to irrigation frequency based on management allowed deficits for container nursery stock. J. Amer. Soc. Hort. Sci. 131:140-148.

Calado, A.M., C.M. Portas, A.G. Ferreira, and M.L.P. Silva. 1992. Percolation loss of macronutrients in processing tomatoes cultivated in sandy soils. Acta Hort. 301:151-158.

DaCosta, M. and B.R. Huang. 2006. Minimum water requirements for creeping, colonial, and velvet bentgrasses under fairway conditions. Crop Sci. 46: 81-89.

Dukes, M.D., L. Cardenas-Lailhacar, and G.L. Miller. 2005. Residential irrigation based on soil moisture. Resource Eng. Technol. Sustainable World 12:4-6.

Ells, J.E., E.G. Kruse, and A.E. McSay. 1989. Scheduling irrigation for cucumbers. HortScience 24:448-452.

Haman, D.Z., A.G. Smajstrla, and D.J. Pitts. 2005. Efficiencies of irrigation systems used in Florida nurseries. Univ. Fla. Institute of Food and Agricultural Sciences Coop. Ext. Serv. Bul. 312.

Henry, J.M., S.N. Wegulo, V.A. Gibeault, and R. Autio. 2005. Turfgrass performance with reduced irrigation and nitrogen fertilization. Intl. Turfgrass Soc. Res. J. 10:93101.

Hensley, D. and J. Deputy. 1999. Using tensiometers for measuring soil water and scheduling irrigation. University of Hawaii, College of Tropical Agriculture and Human Resources, Coop. Ext. Serv. L-10.

Howell, D.C. 2004. Fundamental statistics for behavioral sciences. Thomson Wadsworth, Stamford, CT.

Klute, A. 1986. Water retention: Laboratory methods, p. 635-662. In A. Klute (ed.). Methods of soil analysis. Part 1. Physical and mineralogical methods. 2nd ed. Agron. Monogr. 9. ASA and SSSA, Madison, WI.

Kiziloglu, F.M., U. Sahin, I. Angi, and O. Anapali. 2006. The effect of deficit irrigation on water-yield relationship of sugar beet (Beta vulgaris L.) under cool season and semi-arid climatic conditions. Intl. Sugar J. 108:90-94.

Leskovar, D.I. and G. Piccinni. 2005. Yield and leaf quality of processing spinach under deficit irrigation. HortScience 40:1868-1870.
Morel, P. 2001. Growth control of Hydrangea macrophylla through water restriction. Acta Hort. 548:51-58.

Oki, L.R., J.H. Lieth, and S. Tjosvold. 2001. Irrigation of Rosa bybrida L. 'Kardinal' based on soil moisture tension increases productivity and flower quality. Acta Hort. 547:213-219.

Sachs, R.M., T. Kretchun, and T. Mock. 1975. Minimum irrigation requirements for landscape plants. J. Amer. Soc. Hort. Sci. 100:499-502.

Scheiber, S.M. and R.C. Beeson, Jr. 2006. Petunia growth and maintenance in the landscape as influenced by alternative irrigation strategies. HortScience 41: 235-238.

Smajstrla, A.G. and S.J. Locascio. 1996. Tensiometer-regulated, drip-irrigation of tomato. Appl. Eng. Agr. 12:315-319.

Snedecor, G.W. and W.G. Cochran. 1980. Statistical methods. 7th ed. Iowa State University Press, Ames, IA.

Taylor, R.D., B.W.W. Grout, and J. Hill. 2004. Use of tensiometers-based control system to reduce irrigation of cut flower Dianthus caryophyllus 'Santorini' whilst maintaining flower yield and quality. Acta Hort. 664:647-652.

Thayer, R.L. 1982. Public response to water-conserving landscapes. HortScience 17:562-565.

Trenholm, L.E., E.F. Gilman, G.W. Knox, and R.J. Black. 2002. Fertilization and irrigation needs for Florida lawns and landscapes. Univ. Fla. Institute of Food and Agricultural Sciences Coop. Ext. ENH860.

Wang, S. and F. Zhang. 2004. Effect of different water treatments on photosynthesis characteristics and leaf ultrastructure of cucumber growing in solar greenhouse. Acta Hort. 633:397-401.

Welsh, D.R. and J.M. Zajicek. 1993. A model for irrigation scheduling in container-grown nursery crops utilizing management allowed deficits (MAD). J. Environ. Hort. 11:115-118.

Zhang, B., F. Li, G. Huang, Y. Gan, P. Liu, and Z. Cheng. 2005. Effects of regulated deficit irrigation on grain yield and water use efficiency of spring wheat in an arid environment. Can. J. Plant Sci. 85:829-837. 